\title{
PELATIHAN PENANGANAN ANAK BERKEBUTUHAN KHUSUS BAGI INSTRUKTUR, KONSELOR, DAN RELAWAN YAYASAN MITRA NETRA DAN PERSATUAN TUNANETRA INDONESIA
}

\author{
SPECIAL NEEDS CHILDREN INTERVENTION TRAINING FOR MITRA NETRA AND \\ INDONESIA BLIND UNION COUNSELOR, INSTRUCTOR, AND VOLENTEER
}

\author{
${ }^{1)}$ Alabanyo Brebahama, ${ }^{2)}$ Arif Triman, ${ }^{3)}$ Dewi Kumalasari \\ ${ }^{1,2,3)}$ Program Studi Psikologi, Universitas YARSI, \\ Jl. Letjen Suprapto, Cempaka Putih, Jakarta Pusat, Jakarta \\ Email: alabanyo.brebahama@yarsi.ac.id
}

\begin{abstract}
ABSTRAK
Berdasarkan data Kementerian Sosial tahun 2010, jumlah penyandang disabilitas di Indonesia sudah mencapai 11.580.117 jiwa, dan tunanetra menempati urutan teratas yakni sebesar 3.474.035 jiwa. Sebagai upaya untuk mengatasi masalah ketunanetraan, berdirilah Persatuan Tunanetra Indonesia (PERTUNI) dan Yayasan Mitra Netra. Meskipun sudah lama bergerak dalam bidang pelayanan tunanetra, kedua lembaga tersebut belum memiliki tenaga Psikolog professional. Akibatnya, timbul kendala dalam memberikan layanan psikologis, terlebih ketika muncul fenomena Multi Disable Visual Impairment (MDVI), yaitu jenis disabilitas netra yang disertai dengan hambatan lain, seperti tunanetra dengan disabilitas intelektual, tunanetra dengan Attention Deficit Hyperactive Disorder, dan sebagainya. Berdasarkan permasalahan tersebut, dikembangkanlah program pelatihan penanganan anak berkebutuhan khusus bagi konselor, instruktur, dan relawan kedua lembaga. Pelatihan ini bertujuan untuk membekali peserta dengan definisi, indikator, penanganan awal anak berkebutuhan khusus. Pelatihan ini dilaksanakan selama dua hari dengan peserta sebanyak 26 orang, yang terdiri dari 2 konselor, 8 instruktur, 10 instruktur Yayasan Mitra Netra, dan 6 orang tenaga relawan Yayasan Mitra Netra dan PERTUNI. Materi disampaikan dengan metode ceramah, diskusi, tanya jawab, dan studi kasus. Efektivitas pelatihan diukur dengan menggunakan pre-test dan post-test yang terdiri dari 15 item soal, yang mengukur pemahaman peserta terhadap materi. Berdasarkan hasil pengolahan data dengan teknik One Sample T - Test, terdapat perbedaan yang signifikan antara rata-rata skor pre-test dibandingkan dengan rata-rata skor post-test (sig = 0,000). Hal ini menunjukkan bahwa pelatihan ini efektif dalam meningkatkan pemahaman peserta mengenai penanganan beberapa jenis $A B K$.
\end{abstract}

Kata kunci: Pelatihan Penanganan ABK; Konselor; Instruktur; dan Relawan Yayasan Mitra Netra serta PERTUNI

\begin{abstract}
Based on data from Ministry of Social Republic of Indonesia, the population of disability persons reaches 11.580.117, and the first rank is people with visual impairment with population 3.474.035. In order to solve this problem, Indonesian Blind Union and Mitra Netra Foundation were established to serve blind people. Both of these organization has been giving services for ages, but they still have no psychologist yet. As the result, they have limitation in dealing with visual impaired person problem related to psychological aspect. This problem become more serious when multi disable visual impairment (MDVI) emerges. Baes on this problem, we develop a training program with title "Handling Special Need Children" for counselor, instructor, and volunteer of Indonesian Blind Union and Mitra Netra Foundation. This training will give the participants basic knowledge, early assessment, and early intervention for special needs children. The training was conducted in two days with 26 participants (2 counselor, 10 instructor, and 6 volunteer). Training content delivered by using lecturing, discussion, and case study. Training effectiveness measured by using questionnaire containing 15 items. All of the item measure participant knowledge and comprehension about the training material. By using One Sample T - Test, there was significant different between mean score of post-test compare with mean socre of pre-test (sig $=0,000)$. It shows that this training program is effective in enhancing participants comprehension about special needs children intervention.
\end{abstract}


Keywords: Special Needs Children Intervention Training; Counselor; Instructor; and Volunteer of Mitra Netra Foundation and Indonesian Blind Union

Submitted : 12 Juli 2019 Revision : 1 November 2019 Accepted : 17 Februari 2020

\section{PENDAHULUAN}

Jumlah penyandang disabilitas di dunia semakin meningkat dari tahun ke tahun. Hal ini diketahui melalui data World Health Organization (Pascolini \& Mariotti 2012) yang menunjukkan bahwa jumlah penyandang disabilitas sudah mencapai kurang lebih 600 juta jiwa dari total 6 milyar penduduk dunia. Dari jumlah tersebut, penyandang tuna netra menduduki peringkat pertama dengan jumlah 285.389.000 jiwa (39.356.000 jiwa merupakan totally blind dan 246.024.000 jiwa merupakan low vision). Hal ini mendapatkan perhatian khusus dari WHO karena diperkirakan pada tahun 2020 mendatang, jumlah penyandang tunanetra akan bertambah menjadi dua kali lipat dari jumlah saat ini (Papalia \& Feldman, 2007). Di Indonesia sendiri, jumlah penyandang disabilitas juga mengalami peningkatan. Berdasarkan data dari Kementerian Sosial pada tahun 2010 (Nuansa, dalam Virlia \& Wijaya, 2015) diketahui bahwa jumlah penyandang disabilitas di Indonesia telah menyentuh angka 11.580.117 jiwa. Dari jumlah tersebut, tuna netra menduduki urutan teratas yaitu dengan jumlah 3.474.035 jiwa. Data yang diperoleh Persatuan Tunanetra Indonesia (PERTUNI) juga semakin menguatkan data temuan Kementerian Sosial, yakni terdapat 3,75 juta penduduk Indonesia yang mengalami ketunanetraan dengan beragam sebab. Dengan demikian, dapat disimpulkan bahwa ketunanetraan menjadi salah satu masalah yang dihadapi oleh masyarakat dunia, termasuk Indonesia.

Sebagai upaya untuk membantu pemerintah dalam mengatasi masalah ketunanetraan, berdirilah organisasi kemasyarakatan bernama Persatuan Tunanetra Indonesia (PERTUNI) dan lembaga swadaya masyarakat bernama Yayasan Mitra Netra yang bergerak dalam bidang pelayanan ketunanetraan. Persatuan Tunanetra Indonesia merupakan organisasi kemasyarakatan yang berpusat di daerah Jakarta Pusat, dan berfokus pada pembelaan hak-hak penyandang tunanetra, sekaligus melaksanakan kegiatan yang berkaitan dengan pengembangan tunanetra, seperti belajar huruf Braille, kursus keterampilan pijat tunanetra, komputer bagi tunanetra, pelatihan persiapan memasuki dunia kerja, dan sebagainya. Sementara itu, Yayasan Mitra Netra merupakan lembaga swadaya masyarakat yang berdomisili di Lebak Bulus, Jakarta Selatan, dan memberikan layanan bagi tunanetra, mulai dari pendampingan belajar bagi tunanetra yang bersekolah di institusi formal, pengajaran huruf Braille, orientasi mobilitas, komputer bagi tunanetra, kursus musik, Bahasa Inggris, dan sebagainya. Meskipun kedua organisasi tersebut sudah lama bergerak dalam bidang pelayanan tunanetra, namun mereka belum memiliki tenaga Psikolog professional yang mampu menangani proses asesmen dan konseling. Oleh karena itu, mereka membuka diri terhadap perguruan tinggi yang memiliki Fakultas Psikologi untuk dijadikan sebagai mitra kerja sama dalam kegiatan Pengabdian Masyarakat.

Salah satu isu yang berkembang saat ini adalah semakin banyaknyafenomenal ketunaan ganda yang dikenal dengan istilah Multi Disabled Visual Impaired (MDVI), yaitu tunanetra yang juga memiliki ketunaan lain, seperti: tunanetra dengan spectrum autism, tunanetra dengan Attention Deficit Hyperactive Disorder, tunanetra dengan disabilitas intelektual (mental retardation), dan sebagainya. Di lain pihak, ada pula tunanetra yang justru memiliki potensi kecerdasan superior dibandingkan dengan rekan seusianya (gifted blind). Berbicara mengenai tunanetra, terdapat dua indikator yang digunakan untuk mengidentifikasi ketunanetraan seseorang, yakni ketajaman penglihatan (visual acuity) dan luas lapang pandang (Hallahan dan Kauffman, 2006). Seseorang dinyatakan tunanetra apabila ketajaman penglihatannya kurang dari 20/200 walaupun sudah dibantu dengan menggunakan kacamata. Seseorang juga sudah dikategorikan sebagai penyandang tunanetra apabila luas lapang pandangnya kurang dari 20 derajat. Berdasarkan definisi tersebut, Hallahan, Kauffman, dan Pullen (2009) membagi lagi tunanetra menjadi dua kategori, yakni mereka 
yang buta total (totally blind), dan mereka yang masih memiliki sisa penglihatan (lowvision). Hallahan dan Kauffman (dalam Mangunsong, 2009) menjelaskan bahwa ketunanetraan itu sendiri dapat menimbulkan berbagai dampak negatif, mulai dari hambatan perkembangan kognitif maupun kemampuan konseptual, hambatan perkembangan motorik dan mobilitas, serta hambatan perkembangan sosial. Hambatan perkembangan kognitif dan kemampuan konseptual sendiri dapat berdampak negatif terhadap proses belajar anak. Hambatan perkembangan motorik serta mobilitas akan berpengaruh negatif terhadap kemampuan koordinasi tubuh, maupun suatu objek, landmarks (orientasi) dan untuk bergerak dalam suatu lingkungan. Hambatan perkembangan sosial juga berpengaruh negatif terhadap kemampuan penyesuaian dirinya, mapun keterampilan dalam membina hubungan dnegan orang lain (Mangunsong, 2009). Apabila ketunanetraan itu sendiri sudah memberikan berbagai dampak negatif, tentunya masalah Multi Disable Visual Impaired (MDVI) dapat menimbulkan efek yang jauh lebih besar bagi para penyandangnya.

Untuk dapat mengurangi efek negatif ketunaan yang dimiliki oleh para penyandang disabilitas, penting sekali untuk dilakukan deteksi dini (screening awal), pemberian intervensi yang tepat, baik pada masalah utama maupun masalah sampingan yang melibatkan aspek kognitif, emosi, psikologis, dan sosial. Ketiadaan tenaga Psikolog di kedua lembaga tersebut ternyata berdampak terhadap keterbatasan pemberian layanan, serta kekhawatiran para pekerja dalam memberikan layanan. Selama ini, konselor, pengajar (braille, komputer, dan bahasa), serta relawan (volunteer) di Yayasan Mitra Netra dan Persatuan Tunanetra Indonesia hanya menangani klien dengan ketunanetraan murni. Akibatnya, mereka mengalami kebingungan saat menghadapi klien dengan kekhususan ganda tersebut. Sementara, klien dengan ketunaan ganda tersebut tetap memerlukan layanan rehabilitasi dan pendidikan. Di lain pihak, kedua lembaga tersebut mengalami kendala dalam memberikan pembekalan materi bagi konselor, tenaga pengajar, maupun relawan karena belum adanya tenaga Psikolog yang menjalin kerja sama dengan mereka.

Berdasarkan latar belakang tersebut, dikembangkanlah sebuah program pelatihan bertajuk "Penanganan Anak Berkebutuhan Khusus bagi konselor, instruktur, dan relawan Yayasan Mitra Netra maupun PERTUNI." Kegiatan ini bertujuan untuk meningkatkan pengetahuan maupun pemahaman konselor, instruktur, dan relawan kedua lembaga mengenai Anak Berkebutuhan Khusus selain tunanetra. Selain itu, Selain itu, kegiatan ini juga bertujuan untuk melihat sejauh mana efektivitas modul pelatihan yang dikembangkan dalam meningkatkan pemahaman peserta mengenai Anak Berkebutuhan Khusus.

\section{METODE}

Pelatihan ini diselenggarakan selama dua hari dengan total waktu pelaksanaan selama 12 (dua belas) jam. Saung Harmoni, Yayasan Mitra Netra dipilih sebagai lokasi pelaksanaan kegiatan dengan pertimbangan kemudahan akses bagi peserta tunanetra, sekaligus memastikan seluruh peserta hadir tepat waktu. Jumlah peserta dari pelatihan ini sebanyak 26 orang, yang terdiri dari 2 orang konselor, 10 orang instruktur, dan 6 orang relawan Yayasan Mitra Netra maupun Persatuan Tunanetra Indonesia.

Adapun konten pelatihan berisikan penjelasan materi mengenai definisi, ciri-ciri (indikator), dan cara penanganan awal beberapa jenis kebutuhan khusus, yakni: Mental Retardation, lamban belajar (slow learner), Cerdas Istimwa dan Bakat Istimewa (Gifted and Talented), Attention Deficit Hyperactive Disorder (ADHD), Spectrum Autism, dan Kesulitan Belajar Spesifik. Jenis kebutuhan khusus yang dibahas merupakan masalah yang paling sering dijumpai oleh pengelola Yayasan Mitra Netra dan PERTUNI. Apabila dikaitkan dengan taksonomi Bloom, pelatihan ini berfokus pada ranah kognitif, yakni meningkatkan pengetahuan dan pemahaman peserta mengenai jenis-jenis Anak Berkebutuhan Khusus selain tunanetra, serta intervensi awal yang dapat dilakukan.

$$
\text { Metode yang digunakan dalam }
$$
kegiatan ini adalah pelatihan (training) yang dilaksanakan selama dua hari. Secara spesifik, pelatihan disampaikan dengan metode ceramah, diskusi dan tanya jawab, serta studi kasus. Materi dalam bentuk soft copy dikirimkan dua hari sebelum acara kepada peserta, sehingga mereka yang mengalami 
tunanetra dapat membaca materi dengan menggunakan software pembaca layar (screen reader). Pada hari pelaksanaan kegiatan, pemateri menyampaikan teori dengan menggunakan penjelasan lisan karena sebagian peserta tidak mampu untuk melihat tayangan power point. Setelah penjelasan lisan, pemateri memberikan kesempatan bagi peserta untuk bertanya. Pada sesi terakhir di hari pertama dan kedua, peserta akan diberikan kasus mengenai anak dengan retardasi mental, lamban belajar, ADHD, Spectrum Autism, dan Kesulitan Belajar Spesifik, serta diminta untuk mendiskusikan kasus tersebut dalam kelompok kecil (4 - 5 orang). Metode studi kasus tersebut dikenal pula dengan istilah Problem Based Learning (PBL), dimana output dari diskusi adalah langkah-langkah yang pelru dilakukan oleh kelompok dalam menangani kasus tersebut.

Untuk mengetahui sejauh mana tingkat keberhasilan pelaksanaan pelatihan, dilakukan pula proses evaluasi. Evaluasi dilakukan dengan cara memberikan kuesioner pada saat sebelum kegiatan (pre test) dan setelah kegiatan (post test). Alat ukur yang digunakan adalah lima belas soal pilihan ganda yang mengukur pengetahuan dan pemahaman kognitif peserta mengenai jenis-jenis kebutuhan khusus di luar tunanetra. Kegiatan dikatakan efektif apabila terdapat perbedaan signifikan antara skor pengetahuan sebelum dan setelah mengikuti kegiatan.

\section{HASIL DAN PEMBAHASAN}

Pelatihan penanganan ABK dilaksanakan selama dua hari dengan lokasi pelaksanaan kegiatan di Saung Harmoni, Yayasan Mitra Netra. Kegiatan dimulai dengan pemberian pre-test kepada peserta, kemudian dilanjutkan dengan penyampaian materi mengenai Inteligensi, Disabilitas Intelektual, Lamban Belajar, dan Anak Berbakat (Gifted). Di akhir pertama, kegiatan ditutup dengan studi kasus dan tanya jawab mengenai topik yang sudah dibahas. Di hari kedua, kegiatan diisi dengan penyampaian materi mengenai Spectrum Autism, Asperger Synrome, Kesulitan Belajar Spesifik, dan diakhiri dengan studi kasus mengenai siswa dengan beragam jenis disabilitas sesuai dengan topik yang sudah dibahas. Sebagai penutup kegiatan di hari kedua, dilakukan post-test untuk melihat sejauh mana pemahaman peserta terhadap materi.

Jumlah peserta yang mengikuti pelatihan adalah sebanyak 26 orang, namun hanya 22 orang yang mengikuti sesi pre-test dan post-test sehingga hanya data dari 22 peserta yang dapat dioleh. Efektivitas pelatihan dinilai berdasarkan hasil post test dan pre test yang diisi oleh peserta. Berdasarkan tabel 1, terlihat bahwa terdpat perbedaan signifikan antara raa-rata skor total post test jika dibandingkan dengan rata-rata skor total pre test. Secara kuantitatif, rata-rata skor total post test lebih tinggi dibandingkan dengan rata-rata skor pre test. Hal ini menunjukkan bahwa terdapat peningkatan pemahaman peseta terhadap materi pelatihan yang disampaikan.

Tabel 1. Perbandingan Skor Pre-Test dengan skor Post-Test

\begin{tabular}{|lr|l|r|}
\hline & $\mathrm{t}$ & $p$ & \multicolumn{1}{c|}{ Mean } \\
\hline Pre-Test & 14.766 & .000 & 5.739 \\
\hline Post-Test & 76.721 & .000 & 9.435 \\
\hline
\end{tabular}

Apabila diperhatikan lebih detil, terlihat bahwa skor pre-test memiliki rata-rata hasil yang lebih rendah. Hal ini disebabkan oleh sedikitnya pengetahuan peserta mengenai jenis disabilitas selain tunanetra. Sebab, setiap hari mereka hanya memberikan layanan berupa pelatihan membaca huruf Braille, orientasi mobilitas, Bahasa Inggris, Musik, maupun pendampingan mata pelajaran di sekolah formal. Sementara itu, mereka masih belum banyak memperoleh pelatihan dengan konten materi serupa. Hallahan dan Kauffman (2006) menyebutkan bahwa pemberian layanan bagi penyandang disabilitas hanya dapat optimal apabila pemberi layanan memiliki pengetahuan yang cukup mengenai disabilitas itu sendiri. Hal inilah yang menjadi alasan pentingnya pemberian pelatihan penanganan Anak Berkebutuhan Khusus bagi peserta.

Peningkatan skor post-test yang signifikan setelah pelaksanaan pelatihan menunjukkan keberhasilan peserta dalam penyerapan materi. Apabila dikaitkan dengan Taksonomi Bloom (dalam Santrock, 2010), disebutkan bahwa dalam proses belajar terdapat domain kognitif, afektif, dan psikomotor. Pelatihan ini berfokus pada domain kognitif, yakni meningkatkan pengetahuan dan pemahaman peserta mengenai beberapa jenis 
disabilitas, sehingga rata-rata skor post-test yang lebih tinggi dibandingkan dengan skor pre-test menunjukkan bahwa tujuan pelatihan tercapai jika ditinjau dari domain kogniti level pengetahuan dan pemahaman pada taksomoni Bloom.

Selain memperhatikan peningkatan skor post-test, evaluasi juga melihat performa mereka saat memecahkan permasalahan dalam studi kasus. Secara umum, mereka dipecah ke dalam empat kelompok berbeda, dimana masing-masing menerima satu kasus yang berbeda setiap harinya. Berdasarkan presentasi yang mereka lakukan, enam dari delapan kasus yang diberikan berhasil dianalisa oleh kelompok, sedangkan dua kasus lain belum dapat terpecahkan secara tepat. Apabila dipersentasikan, terlihat bahwa $75 \%$ soal studi kasus dapat dipecahkan oleh kelompok, sehingga dapat mengindikasikan pemahaman mereka yang lebih baik terhadap topik disabilitas selain tunanetra.

Kemudian, evaluasi juga dilakukan dengan meminta umpan balik peserta mengenai materi, narasumber, maupun sarana pendukung pelatihan lainnya. Berdasarkan evaluasi Ppeserta, kegiatan ini mendapatkan apresiasi positif, mulai dari penguasaan narasumber terhadap materi, kemudahan pemahaman peserta terhadap materi, kesesuaian materi dengan kebutuhan peserta, hingga hal-hal teknis seperti waktu pelaksanaan kegiatan, sarana dan prasarana, serta konsumsi.

Meskipun evaluasi menunjukkan bahwa pelatihan ini mampu meningkatkan pemahaman peserta terhadap jenis kebutuhan khusus selain tunanetra, namun masih ditemukan beberapa hal yang perlu menjadi catatan. Pertama, secara kuantitatif jumlah peserta mencapai 26 orang, namun hanya 22 orang yang mengisi soal pre-test dan post-test. Sementara, 4 orang peserta tidak mengikuti pengisian soal, sehingga tidak dapat diikutsertakan dalam proses penghitungan data. Kedua, materi pelatihan belum mencakup pembahasan tentang tunanetra dengan gangguan pendengaran (deaf-blind), tunanetra dengan gangguan fisik (netra-daksa), tunanetraindigo, dan sebagainya. Hal ini disebabkan oleh terbatasnya kompetensi pemateri, serta singkatnya waktu pelatihan. Hal ini tentunya dapat menjadi masukan bagi intervensi selanjutnya.

Netra dan Persatuan Tunanetra Indonesia

\section{KESIMPULAN DAN SARAN}

Berdasarkan pembahasan di atas, dapat disimpulkan bahwa setelah pelatihan, peserta mengalami peningkatan dalam pengetahuan maupun pemahaman mengenai penanganan Anak Berkebutuhan Khusus, yang mencakup Mental Retardation, Spectrum Autism, Asperger Syndrome, Attention Deficit Hyperactive Diskorder (ADHD), Specific Learning Difficulties, dan Slow Learner. Dengan demikian, Pelatihan Penanganan Anak Berkebutuhan Khusus ini efektif dalam meningkatkan pengetahuan, dan pemahaman peserta mengenai jenis kebutuhan khusus selain tunanetra. Kemudian, berdasarkan evaluasi pelatihan secara keseluruhan, dapat disimpulkan bahwa kegiatan ini mendapatkan apresiasi positif, mulai dari penguasaan narasumber terhadap materi, kemudahan pemahaman peserta terhadap materi, kesesuaian materi dengan kebutuhan peserta, hingga hal-hal teknis seperti waktu pelaksanaan kegiatan, sarana dan prasarana, serta konsumsi. Berdasarkan hasil pelaksanaan kegiatan, dan evaluasi pelatihan, terdapat beberapa rekomendasi maupun saran yang dapat diberikan, yaitu:

Pelatihan ini dapat terus dilaksanakan namun dengan target peserta dari organisasi pelayanan disabilitas lain, seperti lembaga pelayanan tunarungu, tunadaksa, dan sebagainya.

Materi pelatihan perlu ditambah, yakni mencakup tentang penanganan tunanetra dengan gangguan pendengaran (deaf-blind), tunanetra dengan gangguan fisik netra-daksa), tunanetra-indigo, dan tunanetra dengan jenis kebutuhan khusus lainnya.

Selain mengirimkan materi sebelum pelaksanaan kegiatan, pelaksana juga dapat mengirimkan versi audio dari materi guna mempermudah peserta tunanetra untuk memahami materi.

\section{DAFTAR PUSTAKA}

Abdillah, D. (2010). Tahun 2020 Jumlah Tunanetra Dunia Menjadi 2X Lipat. Diakses pada tanggal13 Juni 2017, dari http://rehsos.kemsos.go.id/modules.ph $\mathrm{p}$ ? name $=$ News $\&$ file $=$ article $\&$ sid $=107$ 7. 
Anderson, L., Larson, S., Lakin, C., \& Kwak, N. (2002). Children with disabilities: Social roles and family impacts in the NHIS-D. DD Data Brief, 4(1), 1-11.

Hallahan, D. P. \& Kauffman, J. M. (2006). Exeptional Children : An Introductionary Survey of Special Education (3rd ed.) Colombus : Merrill Publising. .

Mangunsong, F. (2009). Psikologi dan Pendidikan Anak Berkebutuhan Khusus Jilid I. Jakarta: Lembaga Pengembangan Sarana Pengukuran dan Pendidikan Psikologi (LPSP3) Kampus Baru UI, Depok.
Netra dan Persatuan Tunanetra Indonesia

Papalia, D.E., Olds, S.W., \& Feldman, R.D. (2007). Human Development 10th ed. USA: McGraw-Hill Companies, Inc.

Pascolini, D. \& Mariotti, S.P. (2012). Global Estimates of Visual Impairment: 2010. British Journal of Ophthalmology, 96, 641-648.

Santrock, J.W. (2010), Educatonal Psychology 5th edition. USA: McGraw-Hill Companies, Inc.

Virlia, S. \& Wijaya, A. (2015). Penerimaan Diri pada Penyandang Tunadaksa.Psychology Forum UMM. 